\title{
THE ANALYSIS OF OIL CONTENT IN SEDIMENT AND COMMUNITY STRUCTURE OF MACROZOOBENTHOS IN BELAWAN WATERS OF MEDAN CITY, NORTH SUMATERA PROVINCE
}

\author{
Doli Juni Setia Tanjung*1, Bintal Amin ${ }^{2}$, Syafruddin Nasution ${ }^{2}$ \\ ${ }^{1}$ Student of the Faculty of Fisheries and Marine Universitas Riau, Pekanbaru \\ ${ }^{2}$ Lecturer at the Faculty of Fisheries and Marine Universitas Riau, Pekanbaru \\ *dolijunisetiatanjung@ gmail.com
}

\begin{abstract}
This research was conducted in March 2019 to determine the oil content in sediment, it's community structure of macrozoobenthos and it's relationship in Belawan Waters of Medan City, North Sumatera. Four sampling stations with five replications in each station were surveyed. The results showed that the average oil content in sediments exceeded the threshold had set by National Academy of Science. Macrozoobenthos found consists of Ocypode quadrata, Scyla serrate, Rotun dicauda, Panaeus sp, Murex tribulus and Nassarius olivaccus. The highest abundance was in Station 3 and the lowest was in Station 2. Diversity index in each station were generally very low. Dominance Index in Station 4 was medium, whilst the other stations were high. Evenness index showed in Station 3 and 4 were in high population, Station 1 was in medium population and Station 2 was in low population. Simple linier regression analyses between oil content in sediment with community structure of macrozoobenthos indicated negative correlation $\left(Y=10,5-0,0001 x, R^{2}=0,0004\right.$ and $\left.r=0,02\right)$ which indicated that the higher the oil content, the lower the macrozoobenthos abundance in sediment.
\end{abstract}

Keywords: Belawan Waters, Oil, Sediment, Macrozoobenthos

\section{PENDAHULUAN}

Perairan Belawan yang berjarak \pm 24 km dari Kota Medan merupakan lokasi pelabuhan terbesar di bagian barat Indonesia yang berhadapan dengan Selat Malaka yang sangat padat lalu lintas kapal dan merupakan salah satu pelabuhan utama di Indonesia yang banyak disinggahi oleh kapal-kapal dengan berbagai ukuran. Perairan Belawan juga digunakan sebagai alur transportasi pengangkutan hasil penangkapan ikan oleh nelayan baik dalam skala kecil maupun skala besar. Aktivitas yang terjadi di Perairan Belawan adalah bongkar muat minyak, dimana kapal-kapal tanker besar dalam negeri maupun luar negeri terkadang melepaskan air ballast di sekitar perairan ini. Hal ini mengakibatkan Laut Belawan sangat rawan terhadap pencemaran laut yang diakibatkan oleh limbah minyak dari aktivitas kapal tersebut (Paramitha, 2014).

Minyak merupakan salah satu parameter penting dalam pencemaran di sekitar perairan kawasan industri, pelabuhan, perkotaan dan pemukiman. Suatu tumpahan minyak di perairan belum tentu merupakan pencemaran lingkungan, tetapi dengan adanya tumpahan minyak di perairan dapat mengakibatkan terjadinya pencemaran lingkungan perairan oleh minyak. Hal ini tergantung pada jumlah 
minyak yang tumpah ke perairan, luas dan kondisi perairan serta dampak yang ditimbulkannya (Amin dan Nurrachmi, 1997).

Perairan yang mengandung minyak akan terdispersi ke kolom dan dasar perairan dan dapat merusak ekosistem termasuk biota makrozoobenthos (Paramitha, 2014). Gholizadeh et al., (2012) menyatakan bahwa perubahan komunitas makrozoobenthos secara spasial tergantung pada ukuran partikel sedimen, bahan organik dan kedalaman perairan. Oleh karena itu makrozoobenthos sering digunakan sebagai bioindikator untuk memonitoring pencemaran perairan (Elias and Bremec, 1994; Reece and Richardson 2000; Gesteira et al., 2003). Ira (2011) menyatakan minyak yang mengendap ke dasar perairan akan menutupi dasar permukaan sedimen perairan, apabila bakteri tidak mampu menguraikan minyak tersebut maka dapat mengganggu benthos atau organisme yang habitatnya di dasar perairan, organisme akan mati dan terjadi pembusukan.

Struktur komunitas didefinisikan sebagai kumpulan populasi yang hidup pada lingkungan tertentu, saling berinteraksi dan bersama-sama membentuk tingkat trofik dengan pola metaboliknya. Sebagai satu kesatuan, komunitas memiliki seperangkat karakteristik yang hanya mencerminkan keadaan dalam komunitas saja, bukan pada masing-masing organisme pendukungnya (Odum 1994).

Makrozoobenthos merupakan organisme yang hidup di permukaan atau di dalam sedimen perairan. Pergerakan makrozoobenthos sangat terbatas dan relatif menetap pada satu substrat tertentu (Barnes and Hughes, 2004) sehingga hewan ini lebih sensitif terhadap gangguan lingkungan misalnya perubahan kualitas air dan sedimen (Smorfield and Gage, 2000; Manoharan et al., 2011). Terjadinya perubahan komposisi spesies dan kelimpahan komunitas makrozoobenthos terutama infauna merupakan respon dari akibat adanya bahan pencemar pada sedimen yang berasal dari aktivitas antropogenik (Nipper, 2000).

Penelitian ini bertujuan untuk mengetahui kandungan minyak pada sedimen dan hubungannya dengan struktur komunitas makrozoobenthos di Perairan Belawan Kota Medan Provinsi Sumatera Utara.

\section{METODE PENELITIAN}

Metode yang digunakan dalam penelitian ini adalah metode survei. Sampel yang diperoleh dari Perairan Belawan (Gambar 1) dianalisis di Laboratorium Kimia Laut dan Biologi Laut Jurusan Ilmu Kelautan Fakultas Perikanan dan Kelautan Universitas Riau. Penempatan stasiun dilakukan dengan purposive sampling yang terdiri dari 4 stasiun dengan 5 kali pengulangan.

Lokasi sampling terdiri dari 4 Stasiun yaitu Stasiun 1 berada di Kawasan Hutan Mangrove Belawan, Stasiun 2 berada di muara Sungai Deli, Stasiun 3 berada di pemukiman penduduk / Dermaga Gabion dan Stasiun 4 berada di PELINDO I.

Prosedur analisis kandungan minyak pada sedimen dilakukan dengan menggunakan metode soxhlet (Woodman dalam Sudarmaji et al., 1997). Sementara Prosedur analisis struktur komunitas makrozoobentos menggunakan rumus Brower et al. (1990).

Pengukuran parameter kualitas air terdiri dari suhu, kecerahan, kecepatan arus, salinitas dan derajat keasaman $(\mathrm{pH})$. 


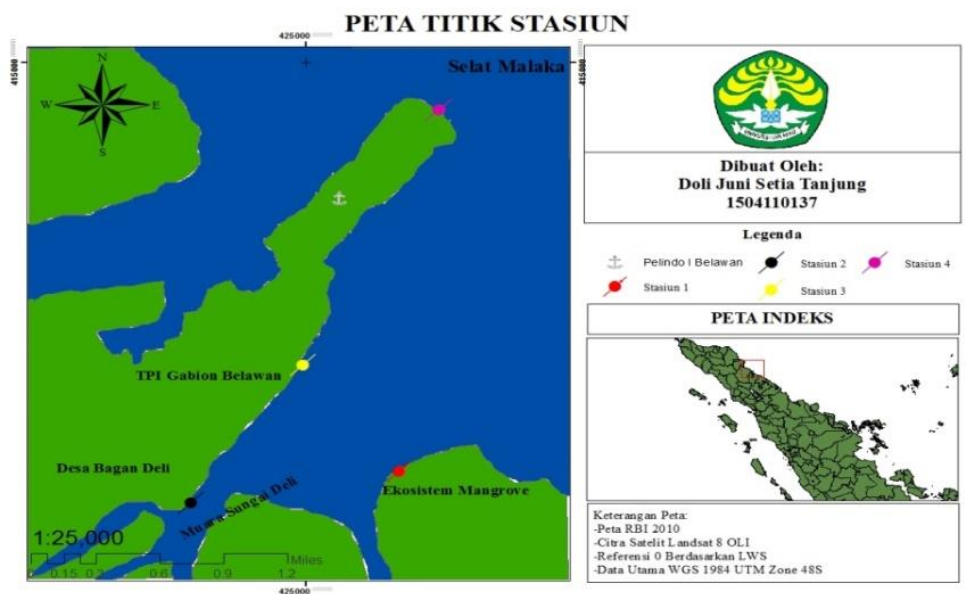

Gambar 1. Peta Lokasi Penelitian

\section{HASIL DAN PEMBAHASAN}

\section{Keadaan Umum Daerah Penelitian}

Secara geografis lokasi penelitian di Perairan Belawan terletak pada $3^{\circ} 46^{\prime} 17^{\prime \prime}$ LU 98'42'22" BT - 348'2" LU 98 43'32" BT yang mempunyai panjang $4,2 \mathrm{~km}$. Belawan merupakan daerah dimana aktivitas penduduknya langsung berhubungan dengan laut. Perairan laut Belawan yang berada di Kecamatan Medan Labuan Provinsi Sumatera Utara banyak digunakan masyarakat setempat untuk berbagai aktivitas. Aktivitas masyarakat di sekitar Laut Belawan antara lain aktivitas industri, perikanan, pelabuhan serta tempat bongkar muat kapal yang mempengaruhi kondisi perairan laut Belawan meliputi: PT. Pelindo, industri pengolahan makanan hasil laut dan pemukiman warga.

Kondisi perairan dari hasil pengamatan di lapangan secara visual adalah seluruh stasiun terlihat keruh dan bewarna kecoklatan serta terdapat lapisan film minyak di sekitaran dermaga dan pelabuhan yang disebabkan oleh adanya aktivitas lalu lintas kapal dan bongkar muat minyak oleh kapal - kapal tanker. Limbah limbah buangan industri serta rumah tangga juga mempengaruhi kondisi Perairan Belawan.

\section{Parameter Kualitas Air}

Parameter yang diukur pada penelitian ini adalah $\mathrm{pH}$, suhu, salinitas, kecerahan dan kecepatan arus. Suhu antara $31-32{ }^{\circ} \mathrm{C}, \mathrm{pH}$ antara 7 - 8, salinitas berkisar $17-30 \mathrm{ppt}$, kecerahan $6-10 \mathrm{~cm}$, kecepatan arus berkisar antara 3,2-5,9 $\mathrm{m} / \mathrm{dtk}$. Hasil pengukuran parameter kualitas air dapat di lihat pada Tabel 1 .

Tabel 1. Parameter Kualitas Air pada Stasiun Pengamatan di Perairan Belawan Kota Medan

\begin{tabular}{ccccccc}
\hline No. & \multirow{2}{*}{ Parameter } & \multirow{2}{*}{ Satuan } & \multicolumn{4}{c}{ Stasiun } \\
\cline { 3 - 6 } & & & $\mathbf{1}$ & $\mathbf{2}$ & $\mathbf{3}$ & $\mathbf{4}$ \\
\hline 1. & Suhu & ${ }^{\circ} \mathrm{C}$ & 31 & 31 & 31 & 32 \\
2. & $\mathrm{pH}$ & - & 7 & 7 & 8 & 8 \\
3. & Salinitas & $\mathrm{Ppt}$ & 24 & 17 & 27 & 30 \\
4. & Kecerahan & $\mathrm{Cm}$ & 7,5 & 10 & 7,5 & 6 \\
5. & Kec. Arus & $\mathrm{m} / \mathrm{s}$ & 4,2 & 5,9 & 3,8 & 3,2 \\
\hline
\end{tabular}

\section{Kandungan Minyak pada Sedimen}

Rata-rata kandungan minyak pada sedimen di perairan Belawan Kota Medan
Provinsi Sumatera Utara berkisar antara 2897,2 - 6306,6 ppm. Untuk lebih jelasnya dapat dilihat pada Tabel 2 dan Gambar 2 
Tabel 2. Kandungan Minyak Sedimen pada Masing-masing Stasiun Pengamatan di Perairan Belawan Kota Medan

\begin{tabular}{ccccccc}
\hline \multirow{2}{*}{ Stasiun } & \multicolumn{5}{c}{ Pengulangan } & \multicolumn{1}{c}{$\begin{array}{c}\text { Rata-rata Kandungan } \\
\text { Minyak per stasiun (ppm) }\end{array}$} \\
\cline { 2 - 6 } & 1 & 2 & 3 & 4 & 5 & \\
\hline 1 & 1894 & 7552 & 8950 & 9472 & 3665 & $6306,6 \pm 3000,2$ \\
2 & 3900 & 3298 & 4143 & 6522 & 2007 & $3974,0 \pm 1473,2$ \\
3 & 460 & 5370 & 1564 & 6634 & 458 & $2897,2 \pm 2597,9$ \\
4 & 489 & 8931 & 2917 & 5586 & 7884 & $5161,4 \pm 3119,9$ \\
\hline
\end{tabular}

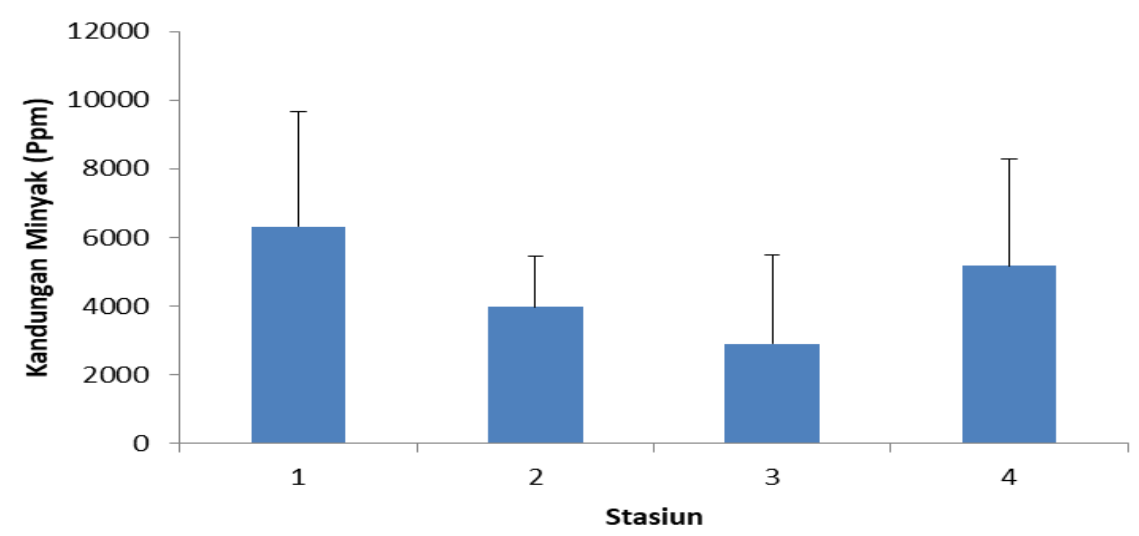

Gambar 2. Rata-rata Kandungan Minyak Pada Masing-masing Stasiun di Perairan Belawan Kota Medan

Berdasarkan analisis kandungan minyak pada sedimen di stasiun 1 yaitu 6306,6 ppm, stasiun 23974 ppm, stasiun 3 2897,2 ppm dan stasiun 4 5161,4 ppm. Rata-rata konsentrasi minyak dalam sedimen di Perairan Belawan telah melewati ambang batas yang telah ditentukan oleh National Academy Science (1 - 100 ppm), sehingga dapat dikatakan bahwa perairan ini sudah tercemar dan membahayakan organisme yang hidup pada dasar perairan tersebut.

Penyebab tingginya kandungan minyak dalam sedimen di Perairan Belawan dikarenakan perairan ini berhadapan langsung dengan jalur transportasi kapal-kapal yang mengangkut minyak di Selat Malaka, serta adanya aktivitas kapal di PT. Pelindo I Belawan, kawasan industri sekitar Muara Sungai Deli, dan kegiatan kapal-kapal nelayan. Selain itu tekstur sedimen di perairan ini didominasi oleh jenis pasir, dimana sedimen pasir mempunyai tingkat akumulasi partikel minyak lebih kuat dibandingkan sedimen lumpur ataupun kerikil (Nybakken, 1992).

Kandungan minyak tertinggi berada pada stasiun 1 (kawasan ini dekat dengan hutan mangrove) dengan rata-rata yaitu 6306,6 ppm kawasan ini berdekatan dengan muara Sungai Deli banyak terdapat aktivitas pelayaran nelayan. Menurut Mukhtasor (2007) air limbah yang berasal dari kapal kadangkala juga mengandung minyak dari tangki bahan bakar. Menurut Widodo (2012) Sumber pencemaran yang masuk ke dalam perairan, dibedakan atas pencemaran yang disebabkan oleh alam (nonpoint resources) dan pencemaran oleh kegiatan manusia (point source). Sumber langsung adalah sumber populasi yang membuang polutan di lokasi spesifik melalui pipa, selokan, atau saluran langsung menuju badan atau permukaan air.

Stasiun 2 memiliki nilai rata-rata kandungan minyak 3974 ppm. Kawasan ini 
berada di muara Sungai Deli, disekitar kawasan ini terdapat banyak industri, terdapat lalu lintas kapal-kapal nelayan, akitivitas antrophogenic. Perairan ini menerima limbah industri dan limbah rumah tangga yang berada di sepanjang aliran Sungai Deli. Aktivitas nelayan juga mengakibatkan perairan ini tercemar oleh minyak.

Tumpahan minyak yang tejadi di laut terbagi kedalam dua tipe, minyak yang larut dalam air dan minyak yang tenggelam dan terakumulasi di dalam sedimen sebagai deposit hitam pada pasir dan batuan-batuan di pantai. Dalam jumlah tertentu, minyak yang tenggelam dan terakumulasi pada sedimen dapat menyebabkan kondisi tidak nyaman bagi organisme laut, khususnya organisme bentik yang hidup di dasar perairan (Usman et al., 2015)

Stasiun 3 memiliki nilai rata-rata kandungan minyak 2897,2 ppm, kawasan ini memiliki kandungan minyak terendah dari stasiun lainnya. Kawasan ini berada dekat dengan pemukiman penduduk, terdapat TPI (Tempat Pelelangan Ikan) dan terdapat dermaga Gabion. Kawasan ini berhadapan dengan Selat Malaka yang memungkinkan minyak tersebar secara merata dan luas. Menurut Lee et al. (2014) minyak di perairan mengalami proses sedimentasi (Sedimentation) yaitu merupakan proses perubahan minyak menjadi sedimen tersuspensi yang akhirnya akan tinggal di kolom air dan terakumulasi pada dasar perairan. Sinking merupakan mekanisme dimana minyak yang berat jenisnya lebih besar dari air akan pindah ke lapisan bawah secara alami karena gaya gravitasi. Sedimentasi memerlukan mekanisme proses untuk merubah minyak menjadi sedimen. Proses sedimentasi minyak lebih cendrung berlangsung melalui rantai makanan dan terdeposit pada dasar laut bersama kotoran buangan organisme laut. Salah satu mekanisme yang terjadi adalah penyebaran butiran minyak ke kolom perairan oleh zooplankton dan tenggelam ke dasar perairan.

Stasiun 4 memililiki kandungan minyak pada sedimen 5161,4 ppm, kawasan ini berada di sekitar Pelabuhan Indonesia (PELINDO I) Belawan terdapat aktivitas bongkar muat kapal, kapal-kapal seperti cargo, tanker, ferry yang melintas di perairan ini yang menyebabkan perairan ini sangat rentan terhadap pencemaran minyak. Kandungan minyak dalam air di Perairan Belawan Kota Medan lebih tinggi dibandingkan dengan penelitian yang dilakukan di Perairan Bungus Teluk Kabung (1), Pertamina UP II Dumai (2), Teluk Jakarta Timur (3), Kawasan Industri Pelitung (4), dan Perairan Depo Pertamina Tanjung Uban (5).

Perbedaan ini disebabkan adanya perbedaan karakteristik peraitan itu sendiri. Wetzel et al., (1980) menyatakan bahwa pada dasarnya penyebaran minyak juga ditentukan oleh beberapa faktor yaitu arus, pasang surut, angin, gelombang, dan morfologi garis pantai. Selain itu letak sumber pencemaran minyak juga mempengaruhi tinggi dan rendahnya kandungan minyak disuatu perairan.

\section{Identifikasi dan Klasifikasi Makrozoobentos}

Hasil identifikasi dan klasifikasi spesies makrozoobenthos yang ditemukan di Perairan Belawan diperoleh 6 spesies. Untuk lebih jelasnya dapat dilihat pada Tabel 3. 
Tabel 3. Klasifikasi Jenis Makrozoobenthos yang ditemukan di Perairan Belawan Kota Medan

\begin{tabular}{|c|c|c|c|c|}
\hline $\begin{array}{l}\text { Filum } \\
\text { Artropoda }\end{array}$ & Kelas & Famili & Genus & Spesies \\
\hline \multirow[t]{4}{*}{ Artropoda } & Malacostraca & Ocypodidae & Ocypode & Ocypode quadrata \\
\hline & & Portunidae & Scyla & Scyla serrate \\
\hline & & Penaeidae & Panaeus & Panaeus sp \\
\hline & Merostomata & Limulidae & Carcinoscorpius & $\begin{array}{l}\text { Carcinoscorpius } \\
\text { Rotundicauda }\end{array}$ \\
\hline Mollusca & Gastropoda & $\begin{array}{l}\text { Muricidae } \\
\text { Nassariidae }\end{array}$ & $\begin{array}{l}\text { Murex } \\
\text { Nassarius }\end{array}$ & $\begin{array}{l}\text { Murex tribulus } \\
\text { Nassarius olivaccus }\end{array}$ \\
\hline
\end{tabular}

\section{Kelimpahan Makrozoobentos}

Kelimpahan rata-rata makrozoobenthos di Perairan Belawan didapatkan yaitu pada Stasiun 1 memiliki kelimpahan rata-rata sebesar $13,33 \mathrm{ind} / \mathrm{m}^{2}$, Stasiun 2 memiliki kelimpahan rata-rata sebesar 1,67 ind $/ \mathrm{m}^{2}$, Stasiun 3 memiliki kelimpahan rata-rata sebesar $21,67 \mathrm{ind} / \mathrm{m}^{2}$ dan Stasiun 4 memiliki kelimpahan rata-rata $3,33 \mathrm{ind} / \mathrm{m}^{2}$. Kelimpahan rata-rata setiap stasiun dapat dilihat pada Tabel 4.

Tabel 3. Kelimpahan Rata-rata Makrozoobentos pada Masing-masing Stasiun Pengamatan di Perairan Belawan Kota Medan

\begin{tabular}{ccccc}
\hline Stasiun & Ulangan & Jumlah individu & Kelimpahan $\left(\mathrm{ind} / \mathrm{m}^{2}\right)$ & Rata-rata $\left(\mathrm{ind} / \mathrm{m}^{2}\right)$ \\
\hline 1 & 1 & 2 & 16,67 & \\
& 2 & 3 & 25 & \\
& 3 & 3 & 25 & $13,33 \pm 4.81$ \\
\hline 2 & 4 & 0 & 0 & \\
& 5 & 0 & 0 & \\
& 1 & 0 & 0 & $1,67 \pm 0,00$ \\
\hline 3 & 3 & 1 & 8,33 & \\
& 4 & 0 & 0 & \\
& 5 & 0 & 0 & $21,67 \pm 5,89$ \\
\hline & 1 & 0 & 0 & \\
& 2 & 7 & 58,33 & \\
& 3 & 6 & 50 & $3,33 \pm 0,00$ \\
& 4 & 0 & 0 & \\
\hline
\end{tabular}

Kelimpahan organisme dalam suatu perairan dapat dinyatakan sebagai jumlah individu persatuan luas. Berdasalkan hasil penelitian kepadatan atau kelimpahan ratarata makrozoobenthos pada stasiun 1 memiliki nilai rata-rata $13.33 \mathrm{ind} / \mathrm{m}^{2}$, stasiun $21,667 \mathrm{ind} / \mathrm{m}^{2}$, staiun 321,667 $\mathrm{ind} / \mathrm{m}^{2}$ dan stasiun $43,33 \mathrm{ind} / \mathrm{m}^{2}$ (Gambar 3). Kelimpahan tertinggi terdapat pada stasiun 3 dengan nilai rata-rata 21,667 ind $/ \mathrm{m}^{2}$ kawasan ini berada didekat pemukiman penduduk, terdapat TPI 
(Tempat Pelelangan Ikan) dan terdapat dermaga Gabion. Kawasan ini memiliki substrat pasir berlumpur, di kawasan ini juga terdapat jasad renik berupa cangkang makrozoobenthos.

Hasil uji anova menunjukkan nilai signifikan $(p>0,05)$ yaitu dengan nilai 0,239 yang memiliki arti bahwa kelimpahan makrozoobenthos antar stasiun tidak berbeda nyata.
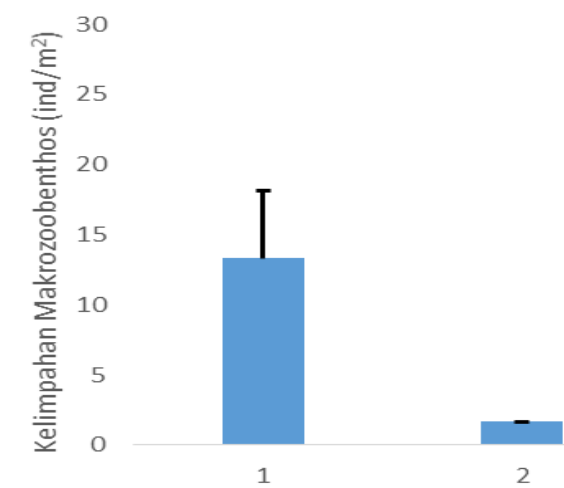

Menurut Odum (1994) Tingginya kepadatan makrozoobenthos diduga karena kandungan organik substratnya yang tinggi sehingga sangat mendukung bagi pertumbuhan makrozoobenthos karena organik substrat yang menjadi bahan makanannya cukup tersedia. Substrat yang kaya akan bahan organik biasanya didukung oleh melimpahnya fauna deposit feeder seperti siput atau Gastropoda.

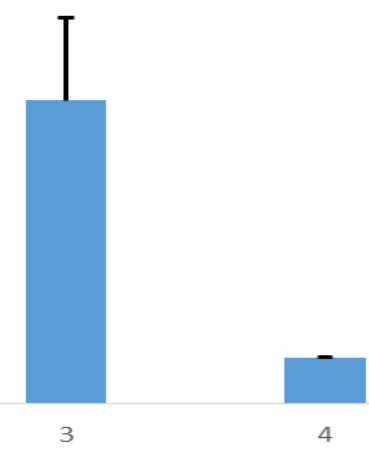

Gambar 3. Kelimpahan Rata-rata Makrozoobenthos pada Masing-masing Stasiun Pengamatan di Perairan Belawan Kota Medan.

\section{Keanekaragaman (H'), Indeks Dominansi (C) dan Keseragaman (E) Makrozoobenthos}

Keanekaragaman $\left(\mathrm{H}^{\prime}\right)$ pada stasiun 1 memiliki nilai rata-rata 0,543560 , staiun 2 memiliki nilai rata-rata 0 , stasiun 3 memiliki nilai rata-rata 0,779343 dan stasiun 4 dengan nilai rata-rata 1 . Keanekaragaman tertinggi berada pada stasiun 4 dengan nilai rata-rata 1 yang berarti memiliki keanekaragaman jenis yang rendah sedangkan pada stasiun 1, 2 dan 3 memiliki indeks keanekaragaman jenis sangat rendah menurut modifikasi dari Lee et al. dalam Soegianto (1994).

Rata-rata indeks keanekaragaman, dominansi dan keseragaman makrozoobenthos dapat dilihat pada Tabel 5 .

Tabel 5. Rata-rata Nilai Indeks Keanekaragaman (H'), Dominansi (C) dan Keseragaman (E) Makrozoobenthos Pada Masing-masing Stasiun di Perairan Belawan Kota Medan.

\begin{tabular}{cccc}
\hline Stasiun & H' & C & E \\
\hline 1 & 0.543560 & 0.781250 & 0.543564 \\
2 & 0 & 1 & 0 \\
3 & 0.779343 & 0.644970 & 0.779350 \\
4 & 1 & 0,5 & 1 \\
\hline
\end{tabular}

Indeks keanekaragaman (H') tertinggi ada pada Stasiun 4 dengan nilai 1 dan terendah pada Stasiun 2 dengan nilai 0. Indeks Dominansi (C) tertinggi ada pada Stasiun 2 dengan nilai 1 dan dominansi terendah ada pada Stasiun 4 dengan nilai
0,5. Sementara keseragaman (E) tertinggi ada pada Stasiun 4 dengan nilai 1 dan keseragaman terendah ada pada Stasiun 2 dengan nilai 0 .

Salah satu penyebab menurunnya keanekaragaman makrozoobenthos adalah 
adanya penurunan kualitas perairan, yaitu rendahnya nilai kandungan oksigen terlarut dan kecerahan, sehingga dapat menghambat aktivitas gangguan sistem penglihatan dan pernapasan dari organisme akuatik (Yunitawati et al., 2012). Sesuai dengan Rahayu et al., (2015) Adanya perbedaan nilai kelimpahan setiap stasiun penelitian berkaitan erat dengan perbedaan ketersediaan bahan organik, substrat, serta aktivitas manusia pada masing -masing kawasan perairan.

Indeks dominansi (C) dinyatakan tinggi jika nilai $\mathrm{C}=1$, hasil diperoleh nilai indeks dominansi pada Stasiun 1 yaitu 0,78125, pada Stasiun 2 yaitu 1, pada Stasiun 3 yaitu 0,644970 dan pada Stasiun 4 yaitu 0,5 . Nilai indeks dominansi pada masing-masing stasiun dikatakan tinggi (kecuali pada Stasiun 4) karena mendekati 1 yang artinya ada jenis yang mendominasi dalam komunitas di setiap stasiun. Hal ini sesuai dengan pernyataan Odum (1994) yang menyatakan bahwa nilai indeks dominansi yang tinggi menyatakan konsentrasi dominansi yang tinggi (ada individu yang mendominansi), sebaliknya nilai indeks dominansi yang rendah menyatakan konsentrasi yang rendah (tidak ada yang dominan). Tingginya dominansi menunjukkan bahwa tempat tersebut memiliki kekayaan jenis yang rendah dengan sebaran yang tidak merata. Adanya dominansi menandakan bahwa tidak semua makrozoobentos memiliki daya adaptasi dan kemampuan bertahan hidup yang sama di suatu tempat.

Keseragaman jenis (E) pada stasiun 1 yaitu 0,543564 , stasiun 2 yaitu 0 , stasiun 3 yaitu 0,779350 dan stasiun 4 yaitu 1 . Pada Stasiun 3 dan 4 di kawasan ini memiliki nilai $>0,6$ yang berarti memiliki nilai keseragaman populasi yang tinggi, Stasiun 1 memiliki nilai keseragaman populasi sedang. Sementara Stasiun 2 memiliki nilai $<0,4$ yang berarti memiliki nilai keseragaman populasi yang rendah. Nilai indeks keseragaman antar stasiun tergolong relatif tidak merata.. Menurut Wilhm and Dorris (1986), keseragaman tinggi apabila $\mathrm{E}>0,6$, keseragaman sedang apabila $0,4>\mathrm{E}<0,6$ dan keseragaman rendah apabila $\mathrm{E}<0,4$. Nilai indeks kemerataan jenis pada 4 stasiun penelitian termasuk beragam yang artinya keseragaman antar spesies relatif tidak merata.

Tipe substrat ikut menentukan jumlah dan jenis organisme bentik di suatu perairan. Macam dari substrat sangat penting dalam perkembangan komunitas organisme bentik. Pasir cendrung memudahkan untuk bergeser dan bergerak ketempat lain. Substrat berupa lumpur biasanya mengandung sedikit oksigen dan karena itu organisme yang hidup didalamnya harus dapat beradaptasi pada keadaan ini (Puspasari et al., 2012). Permukaan substrat dasar akan lebih banyak terdapat nutrient dan kandungan oksigen yang berguna bagi hewan makrozoobenthos (Sya'rani dan Hariadi, 2006).

\section{Hubungan Kandungan Minyak dengan Kelimpahan Makrozoobnenthos.}

Melalui uji regresi linear sederhana, pengaruh kandungan minyak terhadap kelimpahan makrozoobenthos mempunyai persamaan matematis: $\mathrm{y}=10,5-0,0001 \mathrm{x}$. Konstanta $b$ bernilai negatif artinya terjadi hubungan negatif antara kelimpahan makrozoobenthos dengan kandungan minyak, semakin tinggi kandungan minyak maka semakin menurun pula kelimpahan makrozoobenthos. Koefisien determinasi $\left(\mathrm{R}^{2}\right)=0,0004$ artinya $0,04 \%$ kelimpahan makrozoobenthos dipengaruhi oleh kandungan minyak dan sisanya dipengaruhi oleh faktor lingkungan lain, misalnya substrat, cadangan makanan, tingkat adaptasi makrozoobenthos, pengalih fungsian bibir pantai (reklamasi), serta kandungan logam di perairan tersebut. Menurut Tanjung (1994) faktor fisika (suhu, gelombang, dan tipe substrat) faktor kimia (oksigen terlarut, dan salinitas), 
faktor biologi (predasi, kompetisi, dan makanan), mempengaruhi kelimpahan hewan bentos.

Untuk mengetahui hubungan kandungan minyak dengan kelimpahan makrozoobenthos, dilakukan uji regresi linear sederhana dengan $\mathrm{x}=$ nilai kandungan minyak $\mathrm{y}=$ kelimpahan makrozoobenthos. Untuk lebih jelasnya dapat dilihat pada Gambar 4.

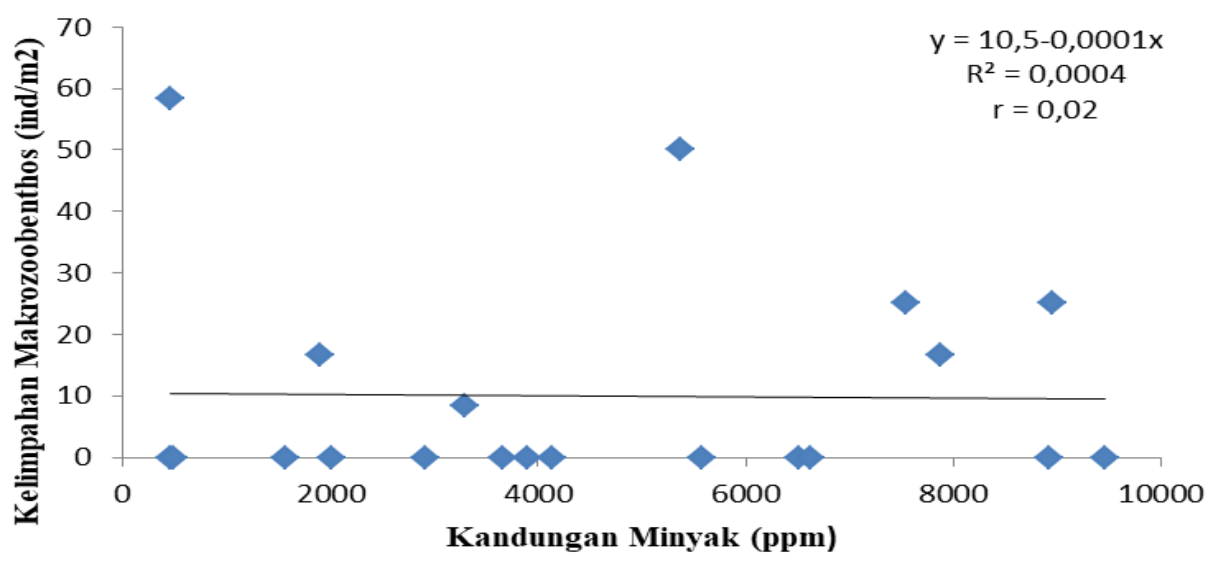

Gambar 4. Hubungan Kandungan Minyak pada Sedimen dengan Kelimpahan Makrozoobenthos

Nilai korelasi merupakan hubungan antara dua variabel yang bersifat kuantitatif. Hubungan dua variabel tersebut dapat terjadi karena adanya hubungan sebab akibat atau dapat pula terjadi karena kebetulan saja. Nilai korelasi pada hubungan kandungan minyak pada sedimen dan hubungannya dengan kelimpahan makrozoobentos di perairan Belawan adalah $\mathrm{r}=0,02$ yang berarti keeratan hubungannya adalah sangat lemah.

Konsentrasi minyak akan mempengaruhi makrozoobenthos apabila keberadaannya berinteraksi secara langsung dengan perairan maupun makrozoobenthos itu sendiri. Selain itu, reaksi kandungan minyak lain yang mempengaruhi langsung keberadaan makrozoobenthos yaitu apabila dicerna langsung oleh makrozoobenthos.

Berdasarkan hasil pengamatan pada penelitian ini maka dapat dilihat bahwa konsentrasi minyak memiliki hubungan yang sangat lemah dengan kelimpahan makrozoobenthos karena adanya pengaruh faktor lain selain minyak. Adapun faktor lain yang mempengaruhi minimnya jumlah makrozoobenthos yaitu adanya aktifitas reklamasi pada pelabuhan yang mengakibatkan substrat pada perairan tersebut tertutup oleh pasir yang contoh paling nyata dapat dilihat pada stasiun 4 .

Penelitian Rosiana et al. (2019) kandungan minyak pada sedimen dan hubungannya dengan kelimpahan makrozoobenthos memiliki hubungan yang negatif, ini berarti kandungan minyak merugikan bagi kelimpahan makrozoobenthos. Minyak pada sedimen berasal dari Pertamina RU II Sei Pakning, aktivitas pelayaran, aktivitas antrophogenic yang menyebabkan perairan rawan tercemar oleh minyak.

Menurut Pratama et al. (2018) tingginya kegiatan aktivitas manusia seperti industri serta pelayaran yang berlangsung secara terus menerus sehingga meningkatkan kandungan minyak yang masuk dan terakumulasi dilaut menyebabkan terganggunya ekosistem makrozoobenthos sehingga dengan meningkatnya kandungan minyak pada sedimen maka kelimpahan makrozoobenthos akan menurun. 
Ketika oil spill terjadi di lingkungan laut, minyak akan mengalami serangkaian perubahan/ pelapukan/ peluruhan (weathering) atas sifat fisik dan kimiawi. Sebagian perubahan tersebut mengarah pada hilangnya beberapa fraksi minyak dari permukaan laut, sementara perubahan lainnya berlangung dengan masih terdapatnya bagian material minyak di permukaan laut. Meskipun minyak yang tumpah pada akhirnya akan terurai/terasimilisi oleh lingkungan laut, namun waktu yang dibutuhkan untuk itu tergantung pada karakteristik awal fisik dan kimiawi minyak dan proses weathering minyak secara alamiah (Nurrachmi et al., 2007; Sulistyono et al., 2018). Maka ini akan menyebabkan pencemaran pada lingkungan laut, lingkungan laut yang tercemar akan menyebabkan terganggunya ekosistem dan juga biota laut seperti makrozoobenthos.

\section{KESIMPULAN DAN SARAN Kesimpulan}

Rata-rata kandungan minyak pada sedimen di perairan Belawan telah melewati ambang batas yang telah ditentukan National Academy Science. Spesies makrozoobenthos yang ditemukan di perairan Belawan meliputi 6 spesies yaitu: Ocypode quadrata, Scyla serrate, Rotun dicauda, Panaeus sp, Murex tribulus dan Nassarius olivaccus. nilai korelasi (r) yaitu 0,02 yang berarti memiliki hubungan yang sangat lemah. Dari hasil penelitian hubungan minyak dengan kelimpahan ratarata makrozoobenthos dapat disimpulkan bahwa kandungan minyak yang tinggi di Perairan Belawan Kota Medan tidak berpengaruh secara langsung terhadap kelimpahan makrozoobenthos dikarenakan adanya faktor lain yang mempengaruhi kelimpahan makrozoobenthos di lokasi penelitian.

\section{Saran}

Untuk penelitian selanjutnya, disarankan untuk meneliti faktor fisika dan kimia yang menyebabkan pencemaran di Perairan Belawan Kota Medan. Adanya reklamasi yang dilakukan oleh PT. PELINDO I seharusnya ada kajian lingkungan yang mempertimbangkan dampak reklamasi terhadap biota yang hidup di Perairan Belawan Kota Medan.

\section{DAFTAR PUSTAKA}

1. Amin, B dan I. Nurrachmi. (1997). Kandungan Minyak dan Efeknya Terhadap Kelimpahan Diatom di Perairan Selat Rupat dan Selat Malaka. Laporan Penelitian. Lembaga Penelitian Universitas Riau. Pekanbaru.

2. Barnes, RSK and RN. Hughes. (2004). An Introduction to Marine Ecology. Edisi 3. Oxford: Blackwell Science Ltd.

3. Brower, J., Z. Jernold., CV. Ende. (1990). Filed and Laboratory Methode for General Ecology. Third Edition. USA: W. M. C. Brown Publisers.

4. Elias, R and CS. Bremec. (1994). Biomonitoring of water quality using benthic communities in Blanca Bay (Argentina). Science of Total Environment, volume 158, pages $45-49$.

5. Gesteira, JLG., JC. Dauvin, MS. Fraga. (2003). Taxonomic level for assessing oil spill effect on soft-bottom sublittoral benthic communities. Marine Pollution Bulletin, volume 46, pages 562-572.

6. Gholizadeh, M., A. Yahya, A. Talib, O. Ahmad. (2012). Effects of environmental factors on polychaete assemblage in Penang National Park, Malaysia. Word Academy of Science. Engineering and Technology Journal, volume 72, pages 669-672. 
7. Ira. (2011). Keterkaitan Padang Lamun Sebagai Pemerangkap dan Penghasil Bahan Organik dengan Struktur Komunitas Makrozoobenthos di Perairan Pulau Barang Lampo. [Tesis]. Institut Pertanian Bogor. Bogor.

8. Lee, SY., JH. Primavera, F. Dahdouh-Guebas, K. McKee, JO. Bosire, S. Cannicci, K. Diele, F. Fromard, N. Koedam, C. Marchand, I. Mendelsohn, N. Mukherjee, and S. Record. (2014). Ecological role and services of tropical mangrove ecosystems: a reassessment. Global Ecology and Biogeography, volume 23, pages 726-743.

9. Manoharan, J., D. Varadharajan, B. Thilagavathi, S. Priyadharsini. (2011). Biodiversity and abundance of benthos along the South East Coast of India. Advances in Applied Science Research, volume 2(6), pages 554-562.

10. Mukhtasor. (2007). Pencemaran Pesisir dan laut. Penerbit PT. Pradnya.

11. Nipper, M. (2000). Current approaches and future direction for contaminant-related impact assessments in coastal environments: Brazilian perspective. Aquatic ecosystem Health and Management, volume 3, pages 433-447.

12. Nurrachmi, I dan B. Amin. (2007). Studi Kandungan Minyak dan Struktur Komunitas Makrozoobenthos di Perairan Sekitar Buangan Limbah Cair Kilang Minyak Pertamina UP II Dumai. Jurnal Perikanan dan Kelautan, volume 12(1), pages 64-70

13. Nybakken, JW. (1992). Biologi Laut. Suatu Pendekatan Ekologis. Gramedia, Jakarta. Penerjemah: Eidman dkk. $459 \mathrm{Hlm}$

14. Odum, EP. (1994). Dasar-dasar Ekologi. Diterjemahkan dari Fundamental of Ecology oleh T. Samingan. Gadjah Mada University Press, Yogyakarta.

15. Paramitha, A. (2014). Studi Klorofil-a di Kawasan Perairan Belawan Sumatera Utara. [Skripsi]. USU : Medan.

16. Puspasari, R., Marsoedi, A. Sartimbul, dan Suhartati. (2012). Kelimpahan Foraminifera Bentik Pada Sedimen Permukaan Perairan Dangkal Pantai Timur Semenanjung Ujung Kulon, Kawasan Taman Nasional Ujung Kulon, Banten. Jurnal Penelitian Perikanan, volume 1(1), pages 1-9.

17. Rahayu. S., R. Mahatma dan Khairijon. (2015). Kelimpahan dan Keanekaragaman Makrozoobentos di Beberapa Anak Sungai Batang Lubuh Kecamatan Rambah Kabupaten Rokan Hulu. Jurnal Online Mahasiswa Fakultas Matematika dan Ilmu Pengetahuan Alam, volume 2(1), pages 198-208.

18. Reece, PF and JS. Richardson. (2000). Biomonitoring with the Reference Condition Approach for the Detection of Aquatic Ecosystems at risk, in Proceedings of a Conference on the Biology and Management of Species and Habitats at Risk, (2) : 549552.

19. Rosiana, K., B. Amin, dan Efriyeldi. (2019). Analisis Kandungan Minyak pada Sedimen dan Hubungannya dengan Kelimpahan Makrozoobentos di Perairan Sungai Pakning Kabupaten Bengkalis Provinsi Riau. [Skripsi]. Fakultas Perikanan dan Kelautan. Universitas Riau. Pekanbaru.

20. Smorfield, PJ., and JD. Gage. (2000). Community structure of the benthos in Scottish Sea-lochs. IV. Multivariatespatial pattern. Marine Biology, volume 136(6), pages 1133 1145.

21. Soegianto, A. (1994). Ekologi Kuantitatif. Penerbit Usaha Nasional. Surabaya.

22. Sudarmadji, S. Hargono, B. Suhardi. (1997). Prosedur Analisa untuk Bahan Makanan dan Pertanian. Liberty. Yogyakarta.

23. Sulistyono. (2018). Dampak Tumpahan Minyak (Oil Spill) di Perairan Laut Pada Kegiatan Industri Migas dan Metode Penanggulangannya. Journal Forum Teknologi, volume 3(1), pages 49-57. 
24. Sya'rani, L dan Hariadi. (2006). Penentuan Sumber Sedimen Dasar Perairan Berdasarkan Analisis Minerologi dan Kandungan Karbonat. Jurnal Ilmu Kelautan, volume 11(1), pages $37-43$.

25. Tanjung, A. (1994). Distribusi Hewan Benthos di Zona Intertidal Pulau Rupat Kabupaten Bengkalis Riau. Laporan Penelitian Lembaga Penelitian Universitas Riau. Pekanbaru. 38 hlm (tidak diterbitkan).

26. Tanjung, A. (2016). Rancangan Percobaan (Ed. Revisi). Bandung : Tantaramesta.

27. Usman, A., S. Nedi, dan B. Amin. (2015). Analisis Kandungan Minyak dalam Air dan Sedimen di Perairan Pantai Rupat Utara dan Selatan. Jurnal Online Mahasiswa (JOM) Bidang Perikanan dan Ilmu Kelautan, volume 5, pages 1-8.

28. Wetzel, R., B. Gopel., RE. Tuner and DF. Whigham. (1980). Ecological Jaipur and International Scientific Publiser, Bombay. 89 hlm

29. Widodo. (2012). Pencemaran Air Raksa (Hg) Sebagai Dampak Pengolahan Bijih Emas di Sungai Ciliunggunung, Waluran, Kabupaten Sukabumi. Jurnal Geologi Indonesia, volume 3(3), pages 139-149.

30. Wilhm, JL. and TC. Doris. (1986). Biologycal Parameter for water quality Criteria. Bio. Science: $18 \mathrm{hlm}$

31. Woodman, AG. (1941). Food Analysis, 4Edition. Mc-Graw Hill Book Company, Inc. New York.

32. Wulandari, T., H. Wahyuningsih., A. Muhtadi. (2016). Struktur Komunitas Makrozoobenthos di Kawasan Mangrove Desa Bagan Deli Kecamatan Medan Belawan. [Skripsi] Medan : Universitas Sumatera Utara.

33. Yunitawati., Sunarto, dan Z. Hasan. (2012). Hubungan Antara Karakteristik Substrat dengan Struktur Komunitas Makrozoobenthos di Sungai Cantigi, Kabupaten Indramayu. Jurnal Perikanan dan Kelautan, volume 3(3), pages 222-227. 